\title{
Pengaruh Model Pembelajaran Kooperatif Tipe Think Talk Write (TTW) dengan Pendekatan Kontekstual terhadap Kemampuan Koneksi Matematis Siswa SMP Negeri 97 Jakarta
}

\author{
Rana Rafidah $^{1, \mathrm{a})}$, Swida Purwanto ${ }^{2, \mathrm{~b})}$, Dwi Antari ${ }^{3, \mathrm{c})}$ \\ ${ }^{1,2,3}$ Universitas Negeri Jakarta \\ Email: a)ranarafidah25@gmail.com
}

\begin{abstract}
Abstrak
Penelitian ini bertujuan untuk mengetahui apakah terdapat pengaruh model pembelajaran kooperatif tipe Think Talk Write (TTW) dengan pendekatan kontekstual terhadap kemampuan koneksi matematis siswa. Penelitian ini merupakan penelitian kuantitatif yang menggunakan metode penelitian eksperimen jenis Quasi Experimental dengan desain penelitian yaitu Posttest Only Control Group Design. Populasi penelitian ini adalah seluruh siswa kelas VIII SMP Negeri 97 Jakarta. Sampel yang diteliti sebanyak 60. Teknik pengambilan sampel dilakukan dengan menggunakan teknik Two-stage Sampling. Langkah pertama pengambilan sampel dimulai dengan teknik Purposive Sampling dan langkah kedua pengambilan sampel dilakukan dengan teknik Cluster Random Sampling. Pada penelitian ini pengumpulan data menggunakan instrumen tes kemampuan koneksi matematis. Uji coba instrumen dilakukan pada siswa kelas IX-A SMP Negeri 97 Jakarta. Sebelum data dianalisis, terlebih dahulu dilakukan uji persyaratan yaitu uji normalitas menggunakan uji Lilliefors dan homogenitas menggunakan uji Fisher. Berdasarkan hasil analisis menggunakan uji- $t$, nilai $t_{\text {hitung }}=3,0520$ dan $t_{\text {tabel }}=1,6716$ yang mengakibatkan $\mathrm{H}_{0}$ ditolak pada taraf signifikan 0,05 . Kemudian pengujian dilanjutkan dengan Cohen-Test untuk melihat besar pengaruh pembelajaran terhadap kemampuan koneksi matematis siswa. Berasarkan hasil perhitungan, diperoleh nilai $d=0,8015$ dengan persentasi $79 \%$ yang berada pada kategori besar. Hal ini menunjukkan bahwa model pembelajaran kooperatif tipe Think Talk Write (TTW) dengan pendekatan kontekstual berpengaruh terhadap kemampuan koneksi matematis siswa.
\end{abstract}

Kata kunci: model pembelajaran Think Talk Write, pendekatan kontekstual, kemampuan koneksi matematis.

\section{PENDAHULUAN}

Matematika memiliki peran besar untuk keberlangsungan hidup manusia karena matematika dapat ditemukan dalam kehidupan sehari-hari, baik konsep maupun aplikasinya. Hal tersebut menjadikan matematika sebagai ilmu yang sangat penting untuk dipelajari dan dipahami sejak dini. Oleh karena itu, matematika diajarkan sebagai salah satu mata pelajaran wajib di setiap jenjang pendidikan, mulai dari tingkat sekolah dasar hingga perguruan tinggi. Sebagai mata pelajaran yang wajib di pelajari, matematika menjadi salah satu indikator yang memengaruhi mutu pendidikan suatu negara.

Indonesia secara rutin mengikuti suatu studi bertaraf internasional yaitu Programme for International Student Assessment (PISA) untuk mengetahui mutu pendidikan Indonesia berdasarkan kemampuan siswa. Kemampuan yang diujikan dalam tes PISA adalah kemampuan literisasi sains, literasi matematika, dan literasi bahasa. Kemampuan literasi matematika didefinisikan sebagai kemampuan individu merumuskan, menggunakan, dan menafsirkan matematika dalam berbagi konteks termasuk bernalar secara matematis dan menggunakan konsep, prosedur, fakta, dan alat matematika dalam menjelaskan serta memprediksi fenomena (Johar, 2012). Hasil studi PISA tahun 2018 menunjukkan bahwa kemampuan literasi matematika Indonesia menduduki peringkat 73 dari 
79 negara dengan perolehan skor 379 di bawah rata-rata skor internasional yaitu 489 (OECD, 2019). Berdasarkan hasil tersebut, masalah matematika yang menuntut kemampuan berpikir tingkat tinggi siswa Indonesia jauh di bawah rata-rata internasional. Kemampuan pemecahan masalah, kemampuan koneksi, kemampuan berpikir kritis dan kreatif siswa di Indonesia masih rendah sehingga siswa lemah dalam menyelesaikan soal-soal tidak rutin yang berkaitan dengan membuktikan, menalar, menggeneralisasi, membuat koneksi, dan menentukan hubungan antara fakta-fakta yang diberikan (Bidasari, 2017). Seorang siswa dikatakan mampu menyelesaikan masalah apabila ia dapat menerapkan pengetahuan yang telah diperoleh sebelumnya ke dalam situasi yang belum dikenal (Bidasari, 2017). Oleh karena itu, dibutuhkan kemampuan yang mengaitkan konsep/aturan matematika yang satu dengan yang lainnya atau dengan aplikasi pada dunia nyata. Kemampuan mengaitkan konsep/aturan matematika yang satu dengan yang lainnya, dengan bidang studi lain, atau dengan aplikasi pada dunia nyata merupakan definisi dari kemampuan koneksi matematis (Suherman, 2008). Berdasarkan hasil studi PISA tahun 2018, terlihat bahwa kemampuan koneksi matematis siswa di Indonesia masih tergolong rendah.

Kemampuan koneksi matematis siswa pada tempat penelitian yaitu SMP Negeri 97 Jakarta juga tergolong rendah. Hal ini ditunjukkan dari analisis penilaian harian siswa sebelum diberi perlakuan. Soal yang dianalis adalah soal yang memenuhi indikator kemampuan koneksi matematis yaitu: (1) memahami hubungan antartopik matematika, (2) menerapkan matematika dalam bidang studi lain atau dalam kehidupan sehari-hari, (3) memahami representasi ekuivalen suatu konsep, (4) mencari hubungan satu prosedur dengan prosedur lain dalam representasi yang ekuivalen, (5) menerapkan hubungan antartopik matematika dan antara topik matematika dengan topik di luar matematika (Sumarmo, 2010).

Soal pertama yang di analisis adalah soal pada indikator memahami hubungan antartopik matematika. Berikut soal yang diberikan:

"Erik dan Tohir masing-maisng memilliki sehelai kertas karton. Karton Erik berbentuk persegi dengan panjang sisinya $(\mathrm{x}+2) \mathrm{cm}$ dan karton Tohir berbentuk persegi panjang dengan ukuran panjang $(\mathrm{x}+8) \mathrm{cm}$ sedangkan lebarnya $(\mathrm{x}-2) \mathrm{cm}$. Bila luas karton mereka sama, maka hitunglah jumlah luas karton mereka".

Soal yang diberikan menguji kemampuan siswa dalam memahami hubungan antara topik geometri dengan topik aljabar sehingga akan terlihat apakah siswa telah memahami konsep operasi aljabar dan dapat menggunakan konsep tersebut untuk menyelesaikan masalah yang berkaitan dengan konsep luas bangun datar. Jumlah siswa yang menjawab benar soal di atas berjumlah 11 dari 36 siswa, menjawab salah 16 siswa, dan sisanya tidak menjawab. Berikut diberikan kesalahan siswa dalam soal:

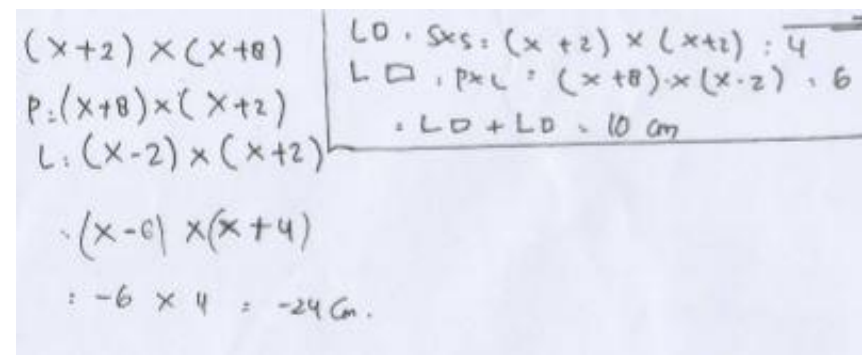

Gambar 1. Kesalahan Siswa Soal 1

Berdasarkan jawaban siswa, terlihat bahwa siswa sudah tepat dalam menentukan rumus luas persegi dan luas persegi panjang, tetapi saat pengaplikasian rumus siswa keliru dalam mengoperasikan bentuk perkalian aljabar sehingga dapat dikatakan bahwa siswa belum memahami konsep operasi aljabar. Dengan demikian, terlihat bahwa kemampuan siswa dalam memahami hubungan antartopik matematika rendah.

Soal yang dianalisis selanjutnya adalah soal pada indikator menerapkan matematika dalam kehidupan sehari-hari. Berikut soal yang diberikan:

"Diketahui harga sepasang sepatu sama dengan dua kali harga sepasang sandal. Pak Syakir membeli 4 pasang sepatu dan 3 pasang sandal. Pak Syakir harus membayar Rp385.000,00. Tentukan harga sepasang sepatu!" 
Soal yang diberikan mengharuskan siswa untuk merancang strategi yang tepat dalam menyelesaikan soal dan menentukan apakah informasi yang tersedia pada soal sudah relevan untuk menyelesaikan masalah yang dihadapi. Jumlah siswa yang menjawab benar soal di atas berjumlah 3 dari 36 siswa, menjawab salah 28 siswa, dan sisanya tidak menjawab. Berikut diberikan kesalahan siswa dalam menjawab soal:

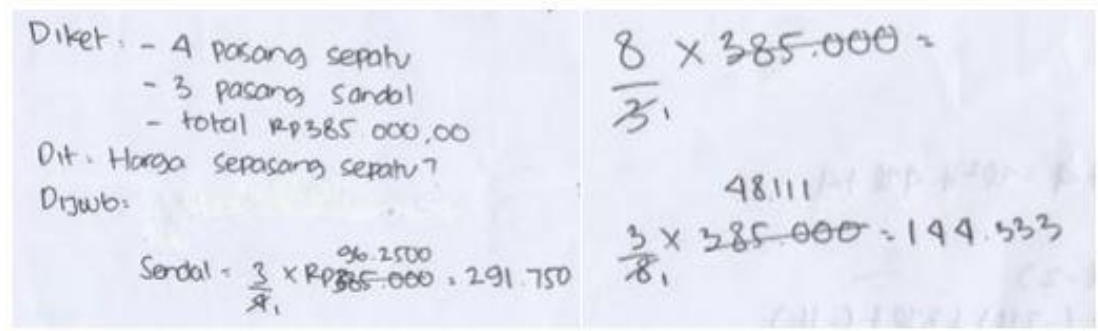

GAMBAR 1. Kesalahan Siswa Soal 2

Kesulitan soal terletak pada strategi penyelesaian yang mengharuskan siswa untuk mengubah hal-hal yang diketahui menjadi sebuah model matematika yang tepat. Kesalahan siswa menunjukkan bahwa siswa tidak memahami informasi yang disajikan pada soal sehingga siswa salah memakai strategi dalam menyelesaikan soal tersebut. Dengan demikian, terlihat bahwa kemampuan siswa untuk menerapkan matematika dalam kehidupan sehari-hari rendah.

Berdasarkan hasil jawaban siswa di SMP Negeri 97 Jakarta, terlihat bahwa kemampuan siswa dalam memahami hubungan antartopik matematika dan menerapkan matematika dalam kehidupan sehari-hari rendah. Kemampuan memahami hubungan antartopik matematika dan menerapkan matematika dalam kehidupan sehari-hari termasuk dalam indikator kemampuan koneksi matematis. Ketidakmampuan siswa dalam memahami hubungan antartopik matematika dan menerapkan matematika dalam kehidupan sehari-hari menunjukkan rendahnya kemampuan koneksi matematis siswa di SMP Negeri 97 Jakarta.

Kemampuan koneksi matematis siswa tidak dapat berkembang dengan sendirinya, melainkan siswa perlu untuk dibimbing dalam mengembangkan kemampuan tersebut (Sulastri, 2017). Menurut NCTM dalam Khaillasiwi (2020), salah satu cara untuk mengembangkan kemampuan koneksi matematis adalah dengan memberikan suatu permasalahan matematika yang dapat diselesaikan dengan menggunakan koneksi matematis. Selain itu, mengembangkan kemampuan koneksi matematis dapat dilakukan dengan menciptakan pembelajaran yang berorientasi pada siswa, dimana guru hanya membimbing siswa untuk menemukan sendiri konsep matematika yang ingin diajarkan. Sebagaimana pernyataan dari Piaget dalam Mentari (2014) bahwa dalam belajar di kelas anak harus aktif. Pembelajaran yang dapat membuat siswa menjadi aktif dalam pembelajaran dan terjadi kerjasama yang baik antara guru dan murid merupakan model pembelajaran kooperatif. Model pembelajaran kooperatif dapat menjadi solusi ideal agar menciptakan lingkungan belajar yang aktif, dimana siswa dapat berinteraksi dengan teman sebayanya dalam kelompok agar dapat memahami pelajaran lebih baik (Rahayu, 2015). Salah satu model pembelajaran kooperatif yang masih jarang digunakan oleh guru di sekolah adalah model pembelajaran Think Talk Write (TTW).

Model pembelajaran Think Talk Write (TTW) berlandaskan pada pembelajaran kontruktivistik yang diterapkan melalui kegiatan berpikir, berbicara, dan menulis (Isrok'atun \& Rosmala, 2018). Model pembelajaran ini memiliki langkah-langkah yang dimulai dari proses berpikir, yaitu siswa membangun sendiri pengetahuannya dan mencari ide atau solusi dari permasalahan konteks yang berkaitan dengan kehidupan sehari-hari atau menyelesaikan masalah yang berkaitan dengan konsep matematika maupun disiplin ilmu lain (Yamin \& Ansari, 2012). Langkah selanjutnya yaitu berbicara atau mengkomunikasikan berbagi ide ataupun solusi yang telah siswa temukan kepada temannya dalam kelompok diskusi. Langkah terakhir yaitu siswa menuliskan ide atau solusi yang didapatkannya dari hasil diskusi. Langkah-langkah TTW yaitu berpikir, berbicara, dan menulis yang telah dipaparkan sebelumnya dapat menjadikan semua siswa terlibat aktif dalam proses pembelajaran. Siswa yang aktif tidak hanya yang berkemampuan unggul saja, tetapi siswa yang kurang unggul juga berusaha untuk mencari ide atau solusi dan menyampaikannya kepada teman sekelompok (Sulastri, 2015). Selain itu, dipilihnya model pembelajaran TTW karena 
berdasarkan hasil penelitian yang telah dilakukan oleh Sugandi (2011) dan Nupriani (2016), model pembelajaran TTW dapat meningkatkan kemampuan koneksi matematis siswa secara signifikan dibandingkan dengan model pembelajaran konvensional. Oleh karena itu, model pembelajaran TTW dapat digunakan sebagai alternatif dalam mengembangkan kemampuan koneksi matematis siswa.

Selain dibutuhkan pembelajaran yang membuat siswa aktif, dibutuhkan juga pembelajaran yang dalam prosesnya menghubungkan pengalaman kehidupan siswa dengan konsep matematika. Adanya proses pembelajaran seperti itu akan membuat pembelajaran lebih bermakna dan diharapkan respon siswa terhadap pembelajaran matematika menjadi lebih baik serta kemampuan koneksi matematis siswa dapat meningkat. Hal tersebut sesuai dengan teori belajar Ausubel dalam Maulana (2011) yang menyatakan bahwa belajar bermakna adalah belajar untuk memahami apa yang telah diperolehnya, kemudian dikaitkan dan dikembangkan dengan keadaan lain sehingga belajarnya dapat lebih dimengerti. Pembelajaran yang dalam prosesnya menghubungkan pengalaman siswa dengan konsep matematika yaitu menggunakan pendekatan kontekstual.

Pendekatan kontekstual adalah suatu pendekatan pembelajaran yang menekankan kepada proses keterlibatan siswa secara penuh untuk dapat memahami materi yang dipelajari dan menghubungkannya dengan kehidupan nyata sehingga mendorong siswa untuk dapat menerapkannya dalam kehidupan mereka (Sanjaya, 2006). Pendekatan kontekstual memiliki tujuh prinsip yaitu konstruktivisme, inkuiri, bertanya, masyarakat belajar, pemodelan, refleksi, dan penilaian sebenarnya (Muslich, 2012). Pada komponen konstruktivisme, kemampuan koneksi matematis dapat dilatih dengan baik. Hal ini didasarkan pada pengertian dari konstruktivisme yaitu proses siswa membangun sendiri pengetahuan di dalam benaknya (Siregar \& Nara, 2011). Pengetahuan tersebut harus siswa kaitkan dengan pengalaman yang pernah dialaminya. Selain itu, dipilihnya pendekatan kontekstual karena berdasarkan hasil penelitian yang telah dilakukan oleh Ulya (2016) dan Retnasari (2016), pendekatan kontekstual dapat meningkatkan kemampuan koneksi matematis siswa secara signifikan dibandingkan dengan pendekatan konvensional. Oleh karena itu, pendekatan kontekstual dapat digunakan sebagai alternatif dalam mengembangkan kemampuan koneksi matematis siswa.

Model pembelajaran kooperatif tipe Think Talk Write (TTW) dengan pendekatan kontekstual merupakan suatu solusi yang dapat membuat pembelajaran matematika lebih bermakna sesuai tujuh komponen utama pendekatan kontekstual dengan menyesuaikan tahapan model pembelajaran TTW. Model pembelajaran TTW dengan pendekatan kontekstual berorientasi pada siswa, dimana guru hanya membimbing siswa untuk menemukan sendiri konsep matematika yang ingin diajarkan sehingga siswa perlu mengaitkan pengetahuan yang telah dimiliki dengan pengetahuan baru yang akan dipelajari. Selain itu, model pembelajaran TTW dengan pendekatan kontekstual menyajikan materi pelajaran dengan mengaitkannya ke dalam kehidupan nyata siswa sehingga siswa dituntut untuk dapat menghubungkan antara pengalaman belajar di sekolah dengan di kehidupan nyata. Berdasarkan penjelasan tersebut, maka penggunaan model pembelajaran TTW dengan pendekatan kontekstual dapat memberikan pengaruh positif terhadap kemampuan koneksi matematis siswa.

\section{METODE}

Penelitian ini merupakan penelitian kuantitatif dan menggunakan metode penelitian jenis Quasi Experimental dengan desain penelitian yaitu Posttest Only Control Group Design. Pada desain ini terdapat dua kelompok yang masing-masing dipilih secara acak. Kelompok yang diberi perlakuan yaitu pembelajarannya menggunakan model Think Talk Write (TTW) dengan pendekatan kontekstual disebut kelas eksperimen dan kelompok yang tidak diberi perlakuan atau pembelajarannya seperti biasa disebut kelas kontrol. Kemudian, kedua kelompok tersebut diberi tes akhir (post-test) kemampuan koneksi matematis yang sama. Populasi pada penelitian ini adalah seluruh siswa kelas VIII di SMP Negeri 97 Jakarta. Langkah pertama pengambilan sampel dimulai dengan teknik Purposive Sampling dengan memilih tiga kelas yang diajar oleh guru yang sama yaitu kelas VIII-D, VIII-E, dan VIII-F. Langkah kedua pengambilan sampel dilakukan dengan menggunakan teknik Cluster Random Sampling untuk memilih dua dari seluruh kelas yang memiliki kondisi awal yang sama (berdistribusi normal, homogen, dan memiliki kesamaan rata-rata). Sampel yang terpilih adalah kelas VIII-E sebagai kelas kontrol dan kelas VIII-F sebagai kelas eksperimen. Instrumen yang 
digunakan pada penelitian ini adalah tes kemampuan koneksi matematis yang sebelumnya sudah diujicobakan instrumen pada siswa kelas IX-A SMP Negeri 97 Jakarta. Teknik analisis data menggunakan uji- $t$ untuk dua sampel independen dengan terlebih dahulu dilakukan uji normalitas menggunakan uji Lilliefors dan homogenitas menggunakan uji Fisher. Selanjutnya, dilakukan Cohen-Test untuk mengetahui besar pengaruh model pembelajaran kooperatif tipe Think Talk Write (TTW) dengan pendekatan kontekstual terhadap kemampuan koneksi matematis siswa.

\section{HASIL DAN PEMBAHASAN}

\section{Hasil}

Data pada penelitian ini diperoleh dari hasil tes kemampuan koneksi matematis siswa. Tes diberikan pada pertemuan ke-6 dengan alokasi waktu 120 menit, setelah kedua kelas diberi perlakuan yang berbeda selama lima pertemuan. Data hasil penelitian disajikan ke dalam bentuk stastistik deskriptif pada tabel 1 .

TABEL 1. Statistik Deskriptif Hasil Tes Kemampuan Koneksi Matematis Siswa

\begin{tabular}{|c|c|c|}
\hline Statistik Deskriptif & Kelas Eksperimen & Kelas Kontrol \\
\hline Banyak Siswa & 30 & 30 \\
\hline Nilai Mininum & 50 & 35 \\
\hline Nilai Maksimum & 90 & 80 \\
\hline Jangkauan Data & 40 & 45 \\
\hline Modus & 75 & 55 \\
\hline Rata-rata & 69 & 58,8333 \\
\hline Quartil Bawah $\left(\mathrm{Q}_{1}\right)$ & 60 & 46,25 \\
\hline Quartil Tengah/Median $\left(\mathrm{Q}_{2}\right)$ & 70 & 57,5 \\
\hline Quartil Atas $\left(\mathrm{Q}_{3}\right)$ & 75 & 70 \\
\hline Jangkauan Antar Quartil & 15 & 23,75 \\
\hline Simpangan Baku & 11,4018 & 14,2444 \\
\hline Varians & 130 & 202,9023 \\
\hline
\end{tabular}

Dari hasil tes kemudian dilakukan uji prasyarat analisis data sesudah perlakuan yaitu uji normalitas dan uji homogenitas. Uji Normalitas dilakukan menggunakan uji Liliefors dengan taraf signifikansi $\alpha=0,05$. Kriteria pengujiannya yaitu terima $H_{0}$ jika $L_{0}<L_{\text {tabel }}$, yang artinya data berdistribusi normal. Hasil uji normalitas sesudah perlakuan disajikan pada tabel 2.

TABEL 2. Hasil Uji Normalitas Sesudah Perlakuan

\begin{tabular}{|c|c|c|c|c|c|}
\hline Kelas & $\boldsymbol{n}$ & $\boldsymbol{L}_{\mathbf{0}}$ & $\boldsymbol{L}_{\text {tabel }}$ & Keterangan & Keputusan \\
\hline Eksperimen & 30 & 0,0903 & 0,1618 & $L_{0}<L_{\text {tabel }}$ & Terima $H_{0}$ \\
\hline Kontrol & 30 & 0,1061 & 0,1618 & $L_{0}<L_{\text {tabel }}$ & Terima $H_{0}$ \\
\hline
\end{tabular}

Berdasarkan tabel 2 terlihat bahwa nilai $L_{0}$ pada kedua kelas kurang dari $L_{\text {tabel }}$, maka dapat disimpulkan bahwa data hasil tes kemampuan koneksi matematis siswa kelas eksperimen dan kelas kontrol berdistribusi normal. Setelah uji normalitas terpenuhi, kemudian data penelitian diuji homogenitasnya menggunakan uji Fisher dengan taraf signifikasi $\alpha=0,05$. Kriteria pengujiannya yaitu terima $H_{0}$ jika $F_{\left(\frac{1}{2} \alpha\right)\left(n_{1}-1, n_{2}-1\right)}<F_{\text {hitung }}<F_{\left(1-\frac{1}{2} \alpha\right)\left(n_{1}-1, n_{2}-1\right)}$, yang artinya keseluruhan data memiliki varians yang homogen. Hasil uji homogenitas sesudah perlakuan disajikan pada tabel 3 . 
TABEL 3. Hasil Uji Homogenitas Sesudah Perlakuan

\begin{tabular}{|c|c|c|l|c|}
\hline $\boldsymbol{F}_{\text {hitung }}$ & $\boldsymbol{F}_{\left(\frac{\mathbf{1}}{\mathbf{2}} \boldsymbol{\alpha}\right)\left(\boldsymbol{n}_{\mathbf{1}}-\mathbf{1}, \boldsymbol{n}_{\mathbf{2}}-\mathbf{1}\right)}$ & $\boldsymbol{F}_{\left(\mathbf{1}-\frac{\mathbf{1}}{\mathbf{2}} \boldsymbol{\alpha}\right)\left(\boldsymbol{n}_{\mathbf{1}}-\mathbf{1}, \boldsymbol{n}_{\mathbf{2}}-\mathbf{1}\right)}$ & Keterangan & Keputusan \\
\hline 0,6407 & 0,4760 & 2,1010 & $\begin{array}{l}F_{(0,025)(29,29)} \\
<F_{\text {hitung }} \\
<F_{(0,975)(29,29)}\end{array}$ & Terima $H_{0}$ \\
\hline
\end{tabular}

Berdasarkan hasil perhitungan diperoleh $F_{\text {hitung }}=1,7052, F_{(0,025)(29,29)}=0,4760$, dan $F_{(0,975)(29,29)}=2,1010$ sehingga $F_{(0,025)(29,29)}<F_{\text {hitung }}<F_{(0,975)(29,29)}$ maka $H_{0}$ diterima. Dengan demikian, dapat disimpulkan bahwa varians dari kelas eksperimen dan kelas kontrol adalah sama atau homogen.

Hasil uji prasyarat analisis data sesudah perlakuan menunjukkan bahwa kelas kontrol dan kelas eksperimen berdistribusi normal dan homogen, sehingga dapat dilanjutkan uji hipotesis penelitian menggunakan uji- $t$ dengan taraf signifikasi $\alpha=0,05$. Kriteria pengujiannya yaitu jika $t_{\text {hitung }}>t_{\text {tabel }}$ maka $H_{0}$ ditolak, yang artinya terdapat pengaruh model pembelajaran kooperatif tipe Think Talk Write (TTW) dengan pendekatan kontekstual terhadap kemampuan koneksi matematis siswa. Hasil pengujian hipotesis dengan uji- $t$ disajikan pada tabel 4.

TABEL 4. Hasil Uji Hipotesis

\begin{tabular}{|c|c|c|c|}
\hline $\boldsymbol{t}_{\text {hitung }}$ & $\boldsymbol{t}_{\text {tabel }}$ & Keterangan & Keputusan \\
\hline 3,0520 & 1,6716 & $t_{\text {hitung }}>t_{\text {tabel }}$ & Tolak $H_{0}$ \\
\hline
\end{tabular}

Hasil pengujian hipotesis dengan uji-t menunjukkan nilai $t_{\text {hitung }}=3,0520$ dan $t_{\text {tabel }}=$ 1,6716 sehingga $t_{\text {hitung }}>t_{\text {tabel }}$ maka $H_{0}$ ditolak. Dengan demikian, dapat disimpulkan bahwa terdapat pengaruh model pembelajaran kooperatif tipe Think Talk Write (TTW) dengan pendekatan kontekstual terhadap kemampuan koneksi matematis siswa.

Pengujian dilanjutkan untuk mengetahui seberapa besar pengaruh model pembelajaran kooperatif tipe Think Talk Write (TTW) dengan pendekatan kontekstual terhadap kemampuan koneksi matematis siswa. Uji besar pengaruh dilakukan menggunakan Cohen-Test. Berdasarkan perhitungan diperoleh nilai $d=0,8015$ yang berada pada kategori besar dengan interpretasinya yaitu $79 \%$ siswa di kelas eksperimen berada di atas rata-rata kelas kontrol.

\section{Pembahasan}

Pada kelas eksperimen, pembelajaran dilakukan dengan mengaitkan konteks kehidupan nyata siswa dengan konsep yang dipelajari. Dihubungkannya konsep matematika dengan kehidupan nyata mengakibatkan siswa memahami bahwa matematika memiliki keterkaitan dengan kehidupan nyata sehingga dapat diaplikasikan dalam kehidupan. Keterkaitan antara konsep yang dipelajarinya dengan kehidupan nyata membuat siswa mudah memahami konsep dan pembelajaran akan lebih bermakna. Pernyataan tersebut berkaitan dengan teori belajar Ausubel yang disebut sebagai teori belajar bermakna. Teori belajar Ausubel dalam Maulana (2011) menyatakan bahwa belajar bermakna adalah belajar untuk memahami apa yang telah diperolehnya, kemudian dikaitkan dan dikembangkan dengan keadaan lain sehingga belajarnya dapat lebih dimengerti. Oleh karena itu, dengan digunakannya pendekatan kontekstual maka kemampuan koneksi matematis siswa dapat meningkat.

Kemampuan koneksi matematis juga dapat meningkat karena adanya model pembelajaran koperatif tipe Think Talk Write (TTW). Sebagaimana hasil penelitian terahulu yang dilakukan oleh Sugandi (2011) dan Nupriani (2016) yang menyatakan bahwa dengan menggunakan model pembelajaran TTW dapat meningkatkan kemampuan koneksi matematis lebih baik dari pada dengan menggunakan model pembelajaran konvensional. Model pembelajaran TTW merupakan pembelajaran yang melatih siswa untuk mengkonstruksi dan menemukan pengetahuan melalui proses berpikir, berbicara atau berkomunikasi, dan menulis. Mengkonstruksi pengetahuan berarti siswa membangun sendiri pengetahuan yang ada di dalam benaknya (Siregar \& Nara, 2011). Pengetahuan 
tersebut harus siswa kaitkan dengan pengalaman yang pernah dialaminya. Dengan demikian, tahapan model pembelajaran TTW dapat mengembangkan kemampuan koneksi matematis siswa. Adanya komponen pendekatan kontekstual dalam tahap Think Talk Write (TTW) menjadi pendukung meningkatnya kemampuan koneksi matematis.

\section{PENUTUP}

\section{Kesimpulan}

Berdasarkan hasil penelitian dapat disimpulkan bahwa terdapat pengaruh model pembelajaran kooperatif tipe Think Talk Write (TTW) dengan pendekatan kontekstual terhadap kemampuan koneksi matematis siswa dengan besar pengaruh 79\%. Interpretasinya adalah $79 \%$ siswa di kelas eksperimen berada di atas rata-rata siswa kelas kontrol. Pengaruh yang diberikan dapat dilihat dari rata-rata nilai tes kemampuan koneksi matematis siswa kelas eksperimen yaitu 69 lebih tinggi dari pada rata-rata nilai tes kemampuan koneksi matematis siswa kelas kontrol yaitu 58,83 .

\section{REFERENSI}

Bidasari, F. (2017). "Pengembangan Soal Matematika Model PISA pada Konten Quantity untuk Mengukur Kemampuan Pemecahan Masalah Matematika Siswa Sekolah Menengah Pertama". Jurnal Gantang. 2 (1): 63-77.

Isrok'atun dan Rosmala, A. (2018). Model-model Pembelajaran Matematika. Jakarta: PT Bumi Aksara.

Johar, R. (2012). "Domain Soal PISA untuk Literasi Matematika". Jurnal Peluang. 1 (1): 30-41.

Khaillasiwi, O., Purwanto, S., \& Meiliasari. (2020). "Pengaruh Model Pembelajaran SSCS (Search, Solve, Create, and Share) terhadap Kemampuan Koneksi Matematis Siswa SMA Negeri 45 Jakarta". Jurnal Riset Pembelajaran Matematika Sekolah. 4 (2): 44-50.

Kurniawan, A. B. \& Erda, G. (2019). "Evaluasi Capaian PISA 2018: Indonesia Perlu Segera Berbenah". Vocational Education Policy White Paper. 1 (21): 1-13.

Maulana. (2011). Dasar-dasar Keilmuan dan Pembelajaran Matematika Sequel 1. Subang: Royyan Press.

Mentari, A., Asri, D. C., \& Rahman, B.(2014). "Meningkatkan Kemampuan Koneksi Matematis Siswa SMP pada Materi Himpunan dengan Metode PenemuanTterbimbing". Prosiding Seminar Nasional Pendidikan Matematika. Jakarta, September 2014: Universitas Muhammadiyah Prof. Dr. Hamka. hlm. 1-9.

Muslich, Masnur. (2012). Pembelajaran Berbasis Kompetensi dan Kontekstual. Jakarta: Bumi Aksara.

Nupriani, F. (2016). "Meningkatkan Kemampuan Komunikasi dan Koneksi Matematik Siswa SMP Melalui Strategi Think Talk Write". Jurnal Buana Ilmu. 1 (1): 45-55.

OECD. (2019). PISA 2018: Insights and Interpretation. Paris: OECD.

Rahayu, W. (2015). Model Pembelajaran Komeks: Bermuatan Nilai-nilai Pendidikan Karakter Aspek Membaca Intensif di SD. Jakarta: Deepublish.

Retnasari, R., Maulana, \& Julia. (2016). "Pengaruh Pendekatan Kontekstual terhadap Kemampuan Koneksi Matematis dan Motivasi Belajar Siswa Sekolah Dasar Kelas IV pada Materi Bilangan Bulat". Jurnal Pena Ilmiah. 1 (1): 391-400.

Sanjaya, W. (2006). Pembelajaran dalam Implementasi Kurikulum Berbasis Kompetensi. Jakarta: Prenada Media Group. 
Siregar, E. dan Nara, H. (2011). Teori Belajar dan Pembelajaran. Bogor: Ghalia Indonesia.

Sugandi, A. I. (2011). "Pengaruh Model Pembelajaran Kooperatif Tipe Think Talk Write terhadap Kemampuan Pemecahan Masalah dan Koneksi Matematis". Prosiding Seminar Nasional Matematika dan Pendidikan Matematika. Yogyakarta, 3 Desember 2011: Universitas Negeri Yogyakarta. hlm. 51-59.

Suherman. (2008). Hands-Out Perkuliahan Belajar dan Pembelajaran Matematika. Bandung: Universitas Pendidikan Indonesia.

Sulastri, I., Irawati, R., \& Karlina, D.A. (2017). "Pengaruh Pendekatan Kontekstual Berstrategi Think Talk Write (TTW) terhadap Kemampuan Koneksi Matematis Siswa pada Materi Perbandingan". Jurnal Pena Ilmiah. 2 (1): 1021-1030.

Sumarmo, U. (2010). Berfikir dan Disposisi Matematik: Apa, Mengapa, dan Bagaimana Dikembangkan Pada Peserta Didik. Artikel pada FPMIPA UPI Bandung.

Ulya, I.F., Irawati, R., dan Maulana. (2016). "Peningkatan Kemampuan Koneksi Matematis dan Motivasi Belajar Siswa Menggunakan Pendekatan Kontekstual". Jurnal Pena Ilmiah. 1 (1): 121-130.

Yamin, M. \& Ansari, B. I. (2012). Taktik Mengembangkan Kemampuan Individual Siswa. Jakarta: Referensi. 